Nurhanisah, Wan Adli \& Khadijah, "Concept of God according to Moses Ben Maimon,” Afkār Vol. 18 Special Issue (2016): 165-198

\title{
CONCEPT OF GOD ACCORDING TO MOSES BEN MAIMON (1138-1204)
}

\section{KONSEP KETUHANAN MENURUT MŪSĀ BIN MAYMŪN} (1138-1204)

\section{Nurhanisah Senin*, Wan Adli Wan Ramli**, Khadijah Mohd Khambali @ Hambali**}

${ }^{* * *}$ Academy of Islamic Studies. University of Malaya. 50603. Kuala Lumpur. Malaysia.

Email: *nurhanisahsenin@gmail.com

\begin{abstract}
Khulasah
Kajian ini bertujuan membahaskan konsep ketuhanan menurut Maimonides. Maimonides memberi penekanan terhadap konsep monoteistik menerusi bukunya The Guide of the Perplexed. Maimonides cuba membuktikan bahawa falsafah sememangnya telah sedia tersirat di dalam perundangan. Oleh itu, artikel ini akan membincangkan hujah Maimonides berkenaan kewujudan Tuhan, keesaanNya dan ketidakjisimanNya. Dalam kewujudan Tuhan, Maimonides telah meletakkan dua kewujudan pada wājib al-wujūd yang membawanya kepada mengatakan bahawa alam ini diciptakan daripada sesuatu yang qadim. Dalam menerangkan mengenai keesaan Tuhan, Maimonides sama sekali menolak Tuhan mempunyai sifat. Adapun dalam membuktikan bahawa Tuhan tidak berjisim, ayat-ayat mutasyābihāt harus difahami dalam bentuk takwilan yang menunjukkan Tuhan tidak berjisim. Ringkasnya, hujah Maimonides dalam membincangkan konsep ketuhanan mempunyai pengaruh Aristotle yang jelas menerusi penekanannya terhadap Tuhan sebagai 'Aql, 'Aqqil dan Ma'qūl.
\end{abstract}

Kata kunci: Maimonides, konsep ketuhanan, kewujudan Tuhan, keesaan, tidak berjisim. 


\begin{abstract}
This study aims to expound Maimonides' discourse on the concept of God. Maimonides strongly emphasized a monotheistic belief of God through his logical arguments which was explicated extensively in his magnum opus The Guide of the Perplexed. Maimonides attempted to demonstrate that philosophy is readily imbued within the law. Hence, this paper will discuss Maimonides' arguments on God's existence, unity and incorporeality. In His existence, Maimonides advocated a dualistic approach to necessary existence as he affirmed that the universe was created however he suggested that it was created from eternal matter. In explaining His unity, Maimonides absolutely refuted subscribing attributes to God's Essence. As for His incorporeality, anthropomorphistic verses must be understood in an equivocal form that demonstrates His incorporeality. In sum, Maimonides' argument on the concept of God clearly resembles the philosophical work of the Aristotelian which affirmed God as the Intellect, Intelligen and Intelligible.
\end{abstract}

Keywords: Maimonides, concept of God, existence of God, unity, incorporeality.

\title{
Introduction
}

For Judaism, the lordship of Yahweh is only meant for the Jews and it does not preach others for conversion as they do not recognize the worship of God in other religions. This entails that monotheism is incapable of uniting the Abrahamic faiths through the concept of God, even though both Islam and Judaism practice a strict monotheism due to differences in the concept of God. ${ }^{1}$

${ }^{1}$ The concept of lordship has been advocated by al-Farouqi in Islam and Other Faith. He mentions on the distinct theory of God between Islam and Judaism in the aspect of lordship. Islam perceives God as the Lord for all humanity whereas Judaism only sees God as a God for the Jewish excluding the gentiles to experience the same God 
In the Jewish world, theological-philosophical thought emerge due to the assimilation of Muslims and Christians in the east and west during the medieval period. The coexisting life consequently sustained them to explain their religion in a rational way vis-à-vis to the others. Besides, the pressure of being converted to Islam or Christ inanity may also somehow mark their vulnerability. Primarily, the Jewish Kalam began to surface in the ninth century along with the influence of the Muslim and Christian theology. ${ }^{2}$ The influence was apparent in the Karaite Jews who was influenced by the Mu'tazilite's rational proofs. ${ }^{3}$ As a result, Islamic and Jewish traditions were both attacked with the rational thought of Mu'tazilite.

with them. As for Islam, the commandments stated in the Qur'an are for all while Jewish believes the commandments are only for them and gentiles only need to adhere with the Noachide commandments. On the other hand, the concept of knowing God in Islam and Judaism also differs as Jewish generally believes that God is a form of personal experience that cannot be judged by others. Whereas, Islam emerged in a comprehensive way, reveals a standard guideline in worshipping and understanding God. See Ismail Raji al-Faruqi, Islam dan Kepercayaan Lain (terj) (Kuala Lumpur: Institut Terjemahan Negara Malaysia Berhad, 2008). Therefore it is impossible to identify the most common way of discussing God. Hence, the researcher decides to study on Maimonides as Jewish scholar, who had deliberated on the concept of God extensively.

2 Direct contact between Jewish scholars such as Muqammas with Christians theologians is obvious in the $9^{\text {th }}$ century where Muqammas who studied under the guidance of his Christian teacher in Nisbis for many years may have very much been influenced with Christian's theology. Simultaneously, Muqammas' Islamic influences can be seen through his exposure of the Aristotelian philosophical material which is mainly written in Arabic form. Sarah Stroumsa, Maimonides in His World: Portrait of a Mediterranean Thinker (Oxfordshire: Princeton University Press, 2009), 34. See also M.Cook, "The Origins of Kalam," Bulletin of the School of Oriental and African Studies, 43 (1980), 32-43.

${ }^{3}$ A Jewish sect who denies the genuinity of Oral Torah as the sayings and discussions of the Rabbinites (religious scholars of the Jews). 
Due to these internal and external counterparts, the urge of providing a comprehensive component in harmonizing between reason and religion was highly in demand which then led to the employment of the philosophical proposition in rationalizing to scripture. Maimonides who was also known as Rambam acronym of Rabbi Moses ben Maimon, embraces philosophy as he believes philosophy has readily imbued within the Scripture. For Maimonides, philosophy is not something alien to religion as the Scripture itself revealed in a rational way which man has to search within. Thus, this study will attempt to expound Maimonides' discourse on the concept of His existence, unity and incorporeality.

\section{Biographical Sketch of Maimonides}

Moses ben Maimon was born in Cordoba, Spain, on 20 March 1135. His father Maimon was a rabbinical judge of Cordoba. He was also popularly known as Rambam, acronym for Rabbi Mosheh Ben Maimon. Maimonides was undeniably the greatest Jewish medieval scholar. David Hartman and Elliott Yagod argue Maimonides' scholarship through his mastery in both Halakhah (Jewish law) and philosophy. ${ }^{4}$

Maimonides was acting as a religious leader of the community. He started supporting himself only after his brother died. He then worked as a doctor and became a physician of Egypt's ruler. He finished writing his commentary on Mishnah at the age of 33 in 1168. Ten years later in 1178, he completed his Mishnah Torah, which comprises 14 books of biblical and Talmudic law. In 1190, he completed his profound philosophical

\footnotetext{
${ }^{4}$ David Hartman \& Elliott Yagod, "God, Philosophy and Halakhah in Maimonides' approach to Judaism," in Multiple Paths to God: Nostre Aetate, 40 Years, eds. John P. Hogan \& George F. McLean (Washington: The Council for Research in Values and Philosophy, 2005), 307-309.
} 
masterpiece, The Guide of the Perplexed. ${ }^{5} \mathrm{He}$ died on 13 December, 1204 in Tiberias. ${ }^{6}$

His embodiment of Jewish law could not be contended. No facet of law was unknown to him as he wrote the Mishneh Torah and summarized the 613 commandments. Besides being a Jewish codifier, he was also a philosopher. Nevertheless, his effort in harmonizing metaphysical philosophy with Jewish traditions entailed arguments and ambiguities towards his philosophical position among later Jewish thinkers. ${ }^{7}$

However, viewing his scholarship from both aspects, it can be concluded that his effort and contribution towards Jewish scholarship is unquestionable. As the basis in Judaism only focuses on practice and not theology, Maimonides was one of the successors who imposed knowledge of God in the first three articles of faith. He did so in order to facilitate Jews understanding God in their practices, which has been widely accepted by Jewish adherents. It is the custom of many congregations to recite the Thirteen Articles ${ }^{8}$, in a slightly more poetic form,

5 This book was written in Arabic and dedicated to his student R. Joseph who was in the quest of harmonizing religion with logical proofs. Maimonides had informed in his introduction that The Guide is certainly for those who wish to inquire more on the esoteric ideas of God. They were the perplexed ones in understanding God in the Bibilical version. Thus, this book is accustomed to address the perplexity of those who request logical explanation of the tradition.

${ }^{6}$ Fred Rosner, "The Life of Moses Maimonides, a Prominent Medieval Physician," Einstein Quarterly 19, 2002, 125-128.

${ }^{7}$ Hartman \& Yagod, God, Philosophy and Halakhah, 307-309.

${ }^{8}$ The Thirteen Articles:

i. Belief in the existence of the Creator, who is perfect in every manner of existence and is the Primary Cause of all that exists.

ii. The belief in G-d's absolute and unparalleled unity.

iii. The belief in G-d's non-corporeality, nor that $\mathrm{He}$ will be affected by any physical occurrences, such as movement, or rest, or dwelling.

iv. The belief in G-d's eternity. 
beginning with the words Ani Maamin "I believe" -- every day after the morning prayers in the synagogue. ${ }^{9}$

Maimonides background certainly had a deep impact on shaping his stance and viewpoint. Living in the golden era of Islam, both halachic and philosophical certainly influenced Maimonides' thought. Moreover, the multicultural and religious environment prepared Maimonides to embrace diverse sources of knowledge, mostly written in Arabic. Maimonides' language was Judaeo-Arabic ${ }^{10}$, which was common for Jewish scholars during his time. This is partly the reason why Maimonides wrote the Guide of the Perplexed in Arabic, although his writing can be considered as polemic against Islam. However, Maimonides also wrote in Hebrew in his Mishneh Torah for his fellow Jews who may only know or prefer that language.

It is known that Maimonides lived under four different rulings. He lived under Almoravid ${ }^{11}$ (Murābitūn)

v. The imperative to worship G-d exclusively and no foreign false gods.

vi. The belief that G-d communicates with man through prophecy.

vii. The belief in the primacy of the prophecy of Moses our teacher.

viii. The belief in the divine origin of the Torah.

ix. The belief in the immutability of the Torah.

x. The belief in G-d's omniscience and providence.

xi. The belief in divine reward and retribution.

xii. The belief in the arrival of the Messiah and the messianic era.

xiii. The belief in the resurrection of the dead.

Chabad.org, The Thirteen Principles of Jewish Faith, http://www.chabad.org/library/article_cdo/aid/332555/jewish/Maimo nides-13-Principles-of-Faith.htm. Accesssed 12 April 2013.

${ }^{9}$ Ibid.

${ }^{10} \mathrm{He}$ used classic Arabic followed by Hebrew words in the citations. Sarah Stroumsa, Maimonides in His World, 19. See also Hopkins, S., "The Languages of Maimonides", in The Trials of Maimonides, 85106.

${ }^{11}$ One of the Berber dynasties of Morocco that conquered Maghreb and Andalus in the $11^{\text {th }}$ century. The dynasty played a crucial role in defending the land from Christian rule. However, it only stood for 85 
reign for ten years in his childhood before it was toppled by the Almohad (Muwahhìidün). Almoravid was known to offer protection and religious freedom to non-Muslims, as decreed by Muslim law. Contrarily, under Almohad rule, Maimonides faced a strict interpretation of Islamic law, which was less favourable to the non-Muslims as most were forced to convert to Islam. Almohad's theological realm, which was founded by Ibn Tumart, undoubtedly was influenced by al-Ghazāli who used to be his teacher. ${ }^{12}$

The Almohad theological standpoint certainly permeated Maimonides' conception of God, which consequently in a way or another prompted him to construct the articles of faith in Judaism. The most apparent Almohad influence is obvious through Maimonides' evaluation of anthropomorphism as incompatible with monotheism. Rejecting anthropomorphism is not rare among Muslims, as Islamic principles had laid a clear-cut rule against idolatry. Nevertheless, the Almohad had apparently advocated this objection through enforcing and declaring it as an article of faith that separates believers from heretics. ${ }^{13}$

On a similar note, Maimonides was not the first to reject anthropomorphism, but he was the one who took charge in outlining the articles of faith for the Jewish society. As mentioned in the Guide ${ }^{14}$ :

"The negation of the doctrine of the corporeality of God and the denial of His having a likeness to create things and of His being subject to affections are matters that

years (1065-1147) before being toppled by Berber rebels led by Ibn Tumart.

${ }^{12}$ Sarah Stroumsa. Maimonides in His World, 69. See also M. Flethcer, "Ibn Tumart's Teachers: The Relationship with al-Ghazali", AlQantara 18, 1997, 305-330.

${ }^{13}$ Sarah Stroumsa, Maimonides in His World, 70.

14 Maimonides, Guide of the Perplexed, trans., S. Pines (Chicago: University of Chicago, 1963), 1: 81 (Pines). 
ought to be made clear and explained to everyone according to his capacity, and ought to be inculcated in virtue of traditional authority upon children, women, stupid ones and those of defective natural disposition, just as they adopt the notion that God is one."

Thus, Maimonides' background under three different rulings, the Almoravid, the Almohad and the Ayyubid, obviously infused diverse thinking into his intellectual journey. The Almoravid enabled him to embrace multiculturalism. Meanwhile, the Almohad taught Maimonides to establish a sturdy faith within Judaism. As for the later period of his life, Maimonides focused on transcribing what he believed, which can be read in his two magnum opus Mishnah Torah and The Guide of the Perplexed. Apart from that, Maimonides' intellectual journey, which no scholar could escape reading its Arab translations of Greek works, indeed extensively influenced Maimonides. As a result, Maimonides found truth in Aristotle's works, consequently adopting Aristotle's method of deliberating the Torah and understanding God.

\section{Maimonides' Methods in Describing God}

Although in the introduction of The Guide he did not directly begin the discussion on philosophy, Maimonides affirmed his stance through exposing the kalām tenets and later refuting their arguments with philosophical proof. His devotion to explaining biblical terms in the first chapter of the Guide did, however, show his dedication to the Law as his fundamental conviction. ${ }^{15}$ In general, Maimonides is recognized as a philosopher -- an Aristotelian philosopher, as he himself associated himself with the Aristotelian thought. He held Aristotle in the

\footnotetext{
${ }^{15}$ Alfred Ivry, The Cambridge Companion to Maimonides, ed. Kenneth Seeskin (Cambridge: Cambridge University Press, 2015), 71.
} 
highest esteem as mentioned in his letter to his translator Samuel ibn Tibbon:

"The writings of Aristotle's teacher Plato are in parables and hard to understand. One can dispense with them, for the writings of Aristotle suffice and we need not occupy [our attention] with the writings of earlier [philosophers]. Aristotle's intellect [represents] the extreme of human intellect"16

This is apparent in Maimonides' communication with his disciple Jospeh Ibn Shim'on (d.1226) and Samuel Ibn Tibbon (d.1230). In a letter to Ibn Tibbon, he compelled them to read Aristotle along with his authoritative commentators such as Alexander of Aphrdisias, Themistius (d. 387) or Ibn Rushd (d.1198). ${ }^{17}$ Although not a single teacher from whom Maimonides learned his philosophy is mentioned, it is possible he learned it on his own.

It is widely known that the Guide contests the theological arguments of the Mutakallimin. Although Maimonides refuted the Muslim kalām, he nevertheless seemed to most often apply dialectical methods over the syllogistic form of the philosophers. It can be seen that Maimonides did very little empirical investigation on his own but instead relied heavily on observing Aristotle. Maimonides' skill in philosophy is nonetheless apparent in his way of presenting arguments logically. ${ }^{18}$ Thus, it can be said that Maimonides had perhaps a lot in common

16 Alexander Marx, "Texts by and about Maimonides: The Unpublished Translation of Maimonides' Letter to Ibn Tibbon," Jewish Quarterly Review, (1934) 25: 374-381.

${ }^{17}$ Sarah Stroumsa, Maimonides in His World, 14. This is particularly mentioned in his letter to Ibn Tibbon. See A. Marx, "Text by and About Maimonides", 374-381.

18 Alfred L. Ivry, "Maimonides, The Guide of the Perplexed," in The Classics of Western Philosophy: A Reader's Guide, eds. Jorge Garcia et al. (Oxford: Blackwell Publishing Ltd. 2003), 129. 
with Muslim theologians themselves and was yet determined to oppose them. His work may not be as heavily philosophical as he wanted.

Maimonides instead indulged in Aristotelian and Neo Platonic philosophies. Maimonides' apophatic theology ${ }^{19}$ (negative theology) appears similar to what the Isma'ili offered during the Fatimid rule. His extreme formulation was deeply influenced by Neoplatonic writings. However, the Isma'ili influence is obvious in the terminology used by an Isma'ili philosopher Hamid al-Din al-Kirmani. Maimonides' statement affirming the positive knowledge achieved through negative apprehension resembles alKirmani's "affirmation by the method of negation". ${ }^{20}$

Moreover, his critical debate on cosmology somehow resonated the Mutakallimin in concluding a created universe. This, however, he demonstrated differently through philosophical argument that he borrowed from Aristotle. This is represented through resonating Platonic and Aristotelian ideas that regard human beings as having a rational nature and being realized in intellectual perfection. The scriptures and traditions are guides for attaining perfection. Maimonides' emphasis on

19 One of the methods of knowing God is negation, which is also known as negative theology. This is also related to mystical experience. Man cannot understand God in a total form, as man can only understand God as much as God has revealed. This is subject to insight from negative theology. The source is an anonymous author known as Dionysius introduced in the late fifth century among the Christians, especially within Christian mysticism. William L. Reese, Dictionary of Philosophy and Religion (USA: The Harvester Press Ltd. 1980), entry: Pseudo Dionysius, 466. The basic premise of negative theology is to gain understanding and experience of what God is not which is believed to be the closest to the nature of God.

20 Maimonides, The Guide of the Perplexed 1.59, 1.60. See Pines. "Shi' ite Terms and Conceptions in the Kuzari," Jerusalem Studies in Arabic and Islam 2, 165-251. See also Joel L. Kreamer, "Moses Maimonides L. An Intellectual Portrait," in The Cambridge Companion to Maimonides. 
philosophical arguments is obvious through his statement where he claimed it as "generally admitted".

In other instance, Maimonides claimed that, "one of the foundations of our Law" is to affirm that "He is the Intellect as well as the Intellectually Cognizing Subject and the Intellectually Cognized Object, and that those three notions form in Him, may He be Exalted, one single notion in which there is no multiplicity". ${ }^{21}$ Although this is rejected by traditionalist Jews, it is undeniable that his philosophical works had a profound impact on non-Jewish philosophers such as Aquinas and Leibniz.

Maimonides' work drew some controversial responses, especially concerning his attempt at integrating philosophy within the Judaic law. This does not mean Maimonides rejected traditions, but rather that Maimonides understood the truth with the articulation of its rationality. Maimonides saw philosophy as something imbued within religion. He claimed with his metaphor of the esotericism of religion that it is similar to 'apples of gold in settings of silver'. Maimonides attempted to demonstrate the ways in which philosophical depth and truth are present in Jewish thought and tradition.

According to Maimonides, revelation is construed from esoteric and exoteric views, which is clear in the figurative verses about God in the Bible. Maimonides delineated the verses twofold. Each verse denotes different underlying meanings, as the truth lies beneath what is written as is the case with anthropomorphism where Maimonides argued that it refers to an eternal and incorporeal God. In other instances, the 'account of the beginning' and the 'account of the chariot' contain truths of the natural world and metaphysics respectively.

The truth in these accounts can be apprehended through a profound thinking and learning process. This leads to Maimonides' central philosophical thought on the

${ }^{21}$ Guide 1.68 . 
Divine, whereby he viewed God as an 'Active Intellect'. God is the Supreme Intellect from which His wisdom inheres and overflows to other intellects. Only intellects that are equipped with moral and wisdom will arrive to the highest intellect, God. Nevertheless, Maimonides did not deny the limitation of reason, which is translated in his negative theology. Following Aristotle's theory, Maimonides also argued that the perfection of the human intellect is the prerequisite of prophecy besides selection by God Himself. This entails the notion of a prophet as a 'philosopher-king'.

The commandments in relation to human nature guide humans in the direction of increasingly rational religion that leads to intellectual cognition, which is to Maimonides true prophecy as well as metaphysics. In the Guide, Maimonides' thesis is in arguing the distinction between esoteric and exoteric teachings of the Bible to the extend that he was understood as naturalistic Aristotelian and on the other hand a Jewish scholar who attempted to harmonise religion with philosophy. ${ }^{22}$

In sum, Maimonides refuted kalām and propositions established by the Mutakallimūn were futile to him in his critics against their proofs of God's existence and unity. In contrary, Maimonides opined that philosophical propositions best prove God's existence, unity and His incorporeality. It is observed that Maimonides integrated Aristotelian and Platonic philosophical thought in his writings. This indicates his influence with Islamic philosophers such as al-Fārāb̄̄ and Ibn Sīnā and is especially obvious in his notion of emanation and active intellect of God.

${ }^{22}$ For instance, as a naturalistic Aristotelian, Maimonides believed in the eternity of the universe. Whereas as an observant Jew, he believed in the Divine creation and will. 
Nurhanisah, Wan Adli \& Khadijah, "Concept of God according to Moses Ben Maimon," Afkār Vol. 18 Special Issue (2016): 165-198

\section{Maimonides' Concept of God}

It is obvious that much like the Almohads, Maimonides advocated true monotheism which stressed the noncorporeality of God, His unity and existence. Although it was mentioned above that the non-corporeal message extends to all community levels despite being mentioned in the Guide that is aimed towards an elite audience. Nevertheless, the message was included in the 13 articles of faith that distinguish a Jewish believer from a nonbeliever. Thus Maimonides emphasized four necessary elements that should be negated from God: corporeality, emotion or change, non-existence and similarity to any creature. In other words, God exists eternally, $\mathrm{He}$ is one and incorporeal.

\section{Existence of God}

In the discussion of God's existence, Maimonides reiterated the Avicennian theory of essence and existence. He affirms that in God's case, essence and existence are identical, as His essence is His existence. God's essence and existence should not be distinguished as He possess Necessary Existence and His Being cannot be associated with any accidents. ${ }^{23}$ This is different from other creations or the sublunar entity. Existence is an accident attached to essence. ${ }^{24}$ God, on the other hand, must not be ascribed with accidents such as attributes. This must be totally rejected as being part of God's essence, as it contains the notion of temporality, whereas God's essence is one and unchanging. As Maimonides mentioned, "It is known that

\footnotetext{
${ }^{23}$ Maimonides. Guide of the Perplexed, 59.

${ }^{24}$ The issue of the relation between essence and existence has spurred a huge discussion among Muslim philosophers. This can be seen in Avicenna and Averroes' debates on whether God's existence and essence are identical or the other way around, as claimed by Averroes. See T. M Rudavsky, Maimonides (Oxford: Wiley Blackwell, 2010), 44.
} 
existence is an accident appertaining to all things and therefore an element superadded to their essence". ${ }^{25}$

Therefore, Maimonides clearly affirmed God as an absolute existence and essence. As mentioned in The Guide:

Accordingly, His existence is identical to His essence and His true reality, and His essence is His existence. Thus, His essence does not have an accident attached to it when it exists, in which case its existence would be a notion that is superadded to it... consequently $\mathrm{He}$ exists, but not through an existence other than His essence. (GP 1.57:132)

Meanwhile, Maimonides also affirmed His existence in his Mishnah Torah with commentary on the following three commandments: (i) "I am the Lord, thy God" (Exod. 20: 2); (2) "Thou shalt have no other gods before me" (Exod. 20: 3); (3) "Hear, 0 Israel: The Lord our God, the Lord is one" (Deut. 6: 4). In his comment on the first of these three commandments, which he takes as the basis of God's existence, he briefly sketches his philosophical arguments for the existence of God with implications to His unity and incorporeality. This is discussed substantially in his Guide of the Perplexed. The second commandment indicates denying polytheism, which Maimonides equally emphasizes. The last commandment demonstrates the unity of God that is also explained further in the Guide. ${ }^{26}$

Maimonides expounded 25 propositions $^{27}$ of philosophers, which inspire the reasoning behind His

${ }^{25}$ Maimonides, Guide of the Perplexed, 80.

${ }^{26}$ Mishneh Torah.

27 There are mainly seven important propositions held by Aristotle:

(P.3) Denial of the infinite regress: "the existence of causes and effects, of which the number is infinite, is impossible." 
Nurhanisah, Wan Adli \& Khadijah, "Concept of God according to Moses Ben Maimon,” Afkār Vol. 18 Special Issue (2016): 165-198

existence and unity. ${ }^{28}$ Nevertheless, it is noted that Maimonides, who was heavily influenced by Aristotle's logic, could no longer ignore his reasoning of cosmological matter. In proving the existence of God, Maimonides first elaborated the argument of His incorporeality. He claimed that the ultimate cause of all genesis and destruction from the motion of spheres requires an agent to cause the motion. Thus, the Mover could neither be corporeally separated from the spheres nor be an indivisible force from the spheres. ${ }^{29}$

The above argument was construed based on Aristotle's physics theory of motion. Although Aristotle

(P.5) Definition of change as motion: "every motion is a change and transition from potentiality to actuality."

(P.17) The existence of movers: "everything that is in motion require a mover by necessity"; this mover can be outside the moved object, or in the body in motion.

(P.19) Definition of possible existence: "everything that has a cause for its existence is only possible with regard to existence with respect to its own essence."

(P.20) Definition of necessary existence: "everything that is necessarily existent with respect to its own essence has no cause for its existence in any way."

(P.25) Definition of a proximate mover: everything is comprised of matter and form. But inasmuch as matter does not move itself, there must be an agent, "a mover that moves the substratum so as to predispose it to receive the form." This mover is the proximate mover, which "predisposes the matter of a certain individual" (GP 2.Intro:239).

(P.26) Eternity of the universe: "I shall add to the premises mentioned before, one further premise that affirms as necessary the eternity of the world. This premise .. . [consists of Aristotle's statement] that time and movement are eternal, perpetual, existing in actu". Maimonides notes in his explication of this premise that Aristotle's arguments in favor of this statement do not constitute a demonstration.

${ }^{28}$ Aristotle is compelled to assume that time and motion are eternity and therefore resulted in the eternity of the universe. Maimonides perceives this to be possible with regard to the propositions of the ${ }_{29}$ philosoph 
did not contest this argument to prove God's existence, it was applied by medieval philosophers and reiterated by Maimonides. God has existed eternally in an actual state and became the eternal cause of motion, known as the First Mover. ${ }^{30}$

Apart from that, Maimonides proved the existence of God through another argument that begins with three possibilities regarding the nature of existence. First, all things are without beginning and end, which means all things are not subject to generation and corruption. Second, all things have beginning and end, which indicates all things are subject to generation and corruption. Third, some are with beginning and end, and some are not subject to generation and corruption. ${ }^{31}$ All things must fall into one of these three categories.

The first argument is certainly absurd, since it is the most sensible to the human intellect that things exist and cease. The second argument is also inadmissible. If everything we perceive were only transient in nature, then all things would be destroyed and no beings would be able to produce anything. ${ }^{32}$ Given that, we must admit our own existence, and subsequently the second argument cannot be accepted. Hence, it is impossible to say that all things either have beginning and end or no things have beginning and end. Maimonides then argued that if we ourselves exist and things around us exist, there must be a being that is not subject to beginning and end, and generation and destruction.

${ }^{30}$ See T. M Rudavsky, Maimonides, 66.

${ }^{31}$ Maimonides, Guide of the Perplexed, 152.

${ }^{32}$ Here, the existence and destruction of all things will happen at the same time if this implies Aristotle's theory of infinite time. The eternal time and motion permit the generation of the universe and others. If time is finite, therefore it is impossible for the universe to exist; as nothing would precede its existence due to the destruction of time. Hence, it is impossible to say all things have a beginning and ending. 
This being is rather a necessary existent and eternal in nature. The necessary existent must be eliminated from plurality, corporeality and relying on any cause for its existence. ${ }^{33}$ Maimonides then summed up the existence of God with reiterating the notion of 'necessary existent' from Ibn Sinā. He also distinguished between contingent and necessary beings, which determines existence with beginning and end and existence without either.

In addition, Maimonides advocated that a necessary being can be either on account of itself or on account of some external force. In the latter case, its existence on its own makes it possible to exist or not to exist. However, its existence is necessary due to the necessary being as the independent existent. It is the effect of the eternal cause and must therefore itself be eternal. ${ }^{34}$

This argument is clearly reiterated by Maimonides from Aristotle's philosophy. The theory of existence is due to the inability to explain the origin of material beings from an immaterial being (God). Therefore, according to philosophers, this eternal being co-exists with God but nevertheless shares a different eternal entity. This eventually leads to the concept of necessary causation which dictates God to be the First Cause

Maimonides elaborated the difference in applying the terms agen and cause in reference to God. According to Maimonides, there is no difference in claiming that both terms are equally correct. However, both imply different connotations in relation to the existence of the universe. The term agen is employed by the mutakallimün and does not allow God to co-exist with the universe. The term cause denotes the implication of God co-existing with the universe and its inseparability from Him. ${ }^{35}$

\footnotetext{
${ }^{33}$ Maimonides, The Guide of the Perplexed, 152.

${ }^{34}$ Ibid., 150.

${ }^{35}$ Ibid., 102.
} 
It also entails understanding of potential and actual as proposed by Aristotle. If the term cause is taken further to the notion of potential and actual, it will lead to God's coexistence with the universe. Unless it is understood as mere actual, this connotes the preceding existence of God. After all, Maimonides agreed with both terms and found no contradiction between them. Even if the Creator is referred to as Agen, ${ }^{36}$ Maimonides affirmed that the work may possibly co-exist with its Agen through the theory of intellect, intelligence and intelligible.

From the argument above, Maimonides seems to introduce the idea of emanation of God who plays a role in sustaining existing forms. Maimonides noted, "It is through the existence of God that all things exist, and it is He who maintains their existence by the process of which is called emanation". ${ }^{37} \mathrm{In}$ another account, Maimonides described God as the force that controls all spheres, with which the spheres possess intellect to comprehend God's command. $^{38}$ Hence, the non-existence of God is impossible, as His non-existence would destroy other existing things too. For God is the end cause and the cause of every existence, be it a distant cause or intermediate cause; in other words, God is the ultimate form of the universe.

Moreover, Maimonides affirmed that God must also be declared the end of all ends and the ultimate cause of everything. The final purpose of a continuous existing

\footnotetext{
${ }^{36}$ Ibid., 104. To Maimonides, God can be seen as the final cause and also agent in every creation. However, God is not similar to other temporal forms. As $\mathrm{He}$ is the Primal Cause, $\mathrm{He}$ possesses no beginning or end and $\mathrm{He}$ is surely not connected to any substance which produces a material form of being such as what Aristotle discussed in the Language of Physics. Maimonides attempts to induce an intellectual form instead of material, which transcends any existing forms that constantly take place.

${ }^{37}$ Maimonides, The Guide of the Perplexed, 104.

${ }^{38}$ Ibid, 118 \& 159.
} 
cause will eventually render to the will of God, or some claim, to the wisdom of God as mentioned by Maimonides. Thus, Maimonides deduced that God is the Agen, the Form and the End, as He cannot be an Agen per se without be attributed as the Ultimate Cause. ${ }^{39}$

Maimonides established the concept of God being the Intellect, Intelligen (intellectually cognizing subject) and Intelligible (intellectually cognized object). Maimonides affirmed that these three notions certainly do not constitute the plurality of His essence. ${ }^{40}$ Although borrowed from other philosophers, his proposition is somewhat different. These notions are also applied based on the emanative concept of God, which is the belief of the Kabbalistic Jews. ${ }^{41}$

For instance, Maimonides mentioned an account "the Lord live" (Ruth iii 13) and not 'by the life of the Lord' that denotes His life is His essence. To Maimonides, His life cannot be separable from His essence. ${ }^{42}$ Therefore, the

${ }^{39}$ Ibid, 104-105.

${ }^{40}$ The intellect, intelligence and intelligible can also be deduced as a result of Maimonides' attempt to reread Aristotle's theory of causation that refers to the physical causation, e.g. a shadow is caused by a body or heat by fire. He negates that from Aristotle's theory and reaffirms Aristotle's causation in the relation of intellect, intellectus and intellectum. In its relation to humans, Maimonides forwards an example of a situation, whereby the intellect refers to the power possessed by someone while the intelligence is the person himself whose power is in a potential moment and only becomes actual when the person acts upon his power. The object results from the act of the intellect and therefore becomes the intelligible. This cycle is suitable to all transient beings except God. Maimonides delineates this from God, as He cannot be associated to potentials, since being in a potential condition would negate His constant and active intellect. Maimonides, The Guide of the Perplexed, 102.

${ }^{41}$ Eliezer Segal, Introducing Judaism (London and New York: Taylor and Francis Group, 2009), 145.

42 This can be seen as parallel to the Mu'tazilite's view on God's essence and attributes. Harry Austryn Wolfson, The Philosophy of the Kalam (Cambridge: Harvard University, 1976), 133. 
three notions is imminence in God: God is the intellect and is always in action as the intelligence that comprehends constantly, and the comprehended objects are those that are likewise His essence.

The Kabbalistic idea of God were somewhat similar to the philosophers' emanative theory. It encompasses ten sefirot, which construe the relation of God with the world. Most names of the sefirot describe God as wise, understanding, glorious, just and so forth, which philosophers commonly refer to as divine attributes. The commonality can be seen further in its origin.

The ten sefirot did not originate from the Kabbalah. However, they appeared in the Middle Age in the book of sefer yezirah (book of creation), which was influenced by the Jewish neo-Pythagoreanism, a Greek philosophical theory. The sefer yazirah advocates the idea that God created the universe by means of permutations and combinations of the ten decimal numbers. ${ }^{43}$

Thus, by affirming overflow unto God, Maimonides went beyond rational and systematic thinking. Nevertheless, by pointing out the emanation of God, he likewise emphasized God's activity as through a separate intellect that overflows like a source of water emanating through every intellect. In addition, it highlighted God as the primary efficient cause who is incorporeal and one. He also causes His knowledge to overflow to the prophets. Thus, His whole action is called overflow.

"The overflow coming from Him for the bringing into being of separate intellects, overflows likewise from these intellects, so that one of them brings another one into being and this continues up to the Active Intellect. With the latter the bringing into being of separate intellects comes to an end. Moreover a certain other act of bringing into being

${ }^{43}$ Eliezer Segal, Introducing Judaism, 146. 
overflows from every separate intellect until the spheres come to an end with the sphere of the moon." ${ }^{44}$

The intellect that overflows from God towards humans is thus the relationship between man and God. If a person attempts to strengthen the intellect, the closer he will get to God. In this sense, it indicates that the mind's activity is beyond systematic thinking.

Besides, Maimonides also held that the sphere possess intelligence (ruling power) that acts as an intermediate element between God and the material world. ${ }^{45}$ This is how the emanating process takes place, as God's indirect influence is immersed through the spheres and the universe. God as the active intellect becomes the intelligence and intelligible.

It can be deduced that Maimonides perceived God's influence and His emanation overflows throughout the spheres. Meanwhile, Aristotle believed that God co-exists with other spheres and the existence of spheres occurs through the continuous cause and effect, where God is considered the First Cause. ${ }^{46}$ It can be seen that both Maimonides and Aristotle perceived God's influence unto the spheres in indirect and direct approaches, respectively.

To Maimonides, it was difficult to imagine God as the direct force behind everything that happens in this world. Therefore, seeing His emanation is more appropriate in describing His incorporeality, as man can only imagine corporeal beings. For Maimonides, to understand the direct cause, one should replace the cause of things through the angels that act upon God's commands. However, in apprehending metaphysics, Maimonides opined that Aristotle tended to adopt too

\footnotetext{
${ }^{44}$ Maimonides, The Guide of the Perplexed, 169-170.

${ }^{45}$ Ibid., 104, 115 \& 159.

${ }^{46}$ Ibid., 170.
} 
much of physical science in his anticipation to figure out the design of God.

Here it can be deduced that in providing proof of God's existence, Maimonides mainly adopted Aristotle's views. Maimonides' proof consists of God being the first cause of motion, He does not move nor is subject to beginning and end, and is one and incorporeal. His essence is an absolute essence devoid of any accidents. The first cause also exists necessarily and does not require any other cause for the deity to exist.

\section{Unity of God}

Maimonides strongly emphasized the unity of God besides His existence and incorporeality. This is apparent in the second proclamation of belief that Maimonides himself established. His argument on God's unity was elaborated extensively in his Guide which pertains to the argument of God as the First Cause.

First, Maimonides argued that God is incorporeal. When one claims that God is incorporeal, it directly demonstrated that He can neither be counted nor divided. Thus, He can only be the cause of every existence. ${ }^{47}$

Secondly, in Aristotle's theory of motion, God is the Prime Mover who moves all things from its potential to the actual form while He remains unmoved. If there are two Gods, both must have shared an element in virtue and another element to distinguish between both. In that case both of them would consist of different elements and neither of them would be the First Cause or have absolutely independent existence but their existence would depend on certain causes or the main element would only be in one of them. Thus this is against the logical reasoning. ${ }^{48}$

\footnotetext{
${ }^{47}$ Ibid., 152.

${ }^{48}$ Ibid., 153.
} 

Maimon," Afkār Vol. 18 Special Issue (2016): 165-198

Thirdly, in Maimonides' argument of God's existence as the necessary existent in its virtue, it demonstrates that God must possess an independent existence which must not cause by others. If there are two Gods, there will be two independent existence and it is impossible to have two First Cause. ${ }^{49}$

Maimonides also argued from the cosmological aspect. God's forces pervade the lowly matter and fashion it. Therefore, if there are two Gods, what cause can determine which God should be active at one time and the other should be at another time. This would cause each of them to be tied to time as his work is tied up with time. Consequently, it leads to the process of passing from potentiality to actuality. Each of them would then need something that would cause him to pass from potentiality to actuality. On the other hand if they were to work together at the same time, they would thus need cooperation and their action would not be independent. Thus, God is one and there cannot be more than one God. $^{50}$

Another aspect which is closely related to His unity is the concept of attributes. Maimonides considered attributes as an element superadded to an essence. Attributes associated with an object, denote two possibilities. First it is the essence of the object itself. If it is, attribute is only a repetition or explanation of a name. As for instance 'man is man' or 'man is a speaking animal'. Second, attribute is superadded element to an object. This is considered as an accident for everything that is superadded to the essence of the object does not form the essential part of the essence and hence forming plurality. ${ }^{51}$ Thus, it contradicts the principle of unity of

\footnotetext{
${ }^{49}$ Ibid., 154.

${ }^{50}$ Ibid., 154.

${ }^{51}$ Ibid., 68.
} 
God. Maimonides hence believes that attribute is neither His essence nor an element superadded to His essence.

To Maimonides, those who believe that God is one but possesses many attributes are declaring unity in their lips but plurality in their thoughts. Belief as being understood is supposed to be verbalized externally and apprehended internally. Maimonides further affirmed that belief has to come after a true apprehension which consists of conviction that the existent exists in our mind is actually in reality beyond our mind. This is because true conviction eliminates illogical explanation of belief and deviation from the correct one. ${ }^{52}$

Fifthly, attributes that is described through actions. Certainly this is not related to the inherent talent or capacity (malakah) of a certain work as what expressed in 'carpenter', 'painter' and 'smith'; for it reiterates the qualities which are mentioned above. However, different attributes that does not describe the creator can be devoted to the essence of God which also does not imply substances towards it. ${ }^{53}$

Maimonides forwards an example as such, Zayd who made the door, built the wall etc. This demonstrates the relation of God to His creations through their nature of existence. Thus, attributes which can be associated to God are attributes that describe His multitude actions which do not imply superadded elements and multiple essences. ${ }^{54}$

Maimonides' refutation of attributes can be seen due to his strict principle of God's unity and necessary existent which was adopted from the framework of Ibn Sīnā. ${ }^{55}$ Although the Scripture mentioned attributes describing

\footnotetext{
${ }^{52}$ Ibid., 67.

${ }^{53}$ Ibid., 72.

${ }^{54}$ Rudavsky, Maimonides, 66.

${ }^{55}$ S. Pines, The Philosophic Sources of the The Guide of the Perplexed. Xciv. See also Z. Diesendruck, "Maimonides' Theory of the Negation of Privation" (Proceedings of the American Academy for Jewish Research, vol. 6 (1934 - 1935)), 139-151.
} 
God, Maimonides argued it should be perceived as His actions in an utmost perfection. ${ }^{56}$ His stance derived from the act of Moses who asked God for the knowledge of His attributes and His essence. And He replied "I will make all my goodness to pass before thee" (ib.19).

Here Maimonides interprets the word goodness to reflect His act of creation. Through His creation, human perceive and eventually subscribe God with attributes such as merciful. ${ }^{57}$ Here it can be seen that Maimonides attempts to relate God with the creation through His will and power that describe His attributes of acts.

Maimonides undertook his position on the attributes of God subscribed by the Torah with the principle "The Torah speaks in the language of man" as the similar qualities being described to God and all beings. Nevertheless, they are essentially attributes to qualify His action without any reference to His essence and indicate absolute perfection. Maimonides supported those who believe that "God is omnipotent by His essence, wise by His essence, living by His essence and endowed with a will by His essence." ${ }^{58}$ It is intelligible to denote His single essence to create multiple different actions at the same time does not cause any compounds to the essence.

Apart from predicating attributes to actions, Maimonides' affirmative stance towards the unity and incorporeality of God entails him to negate attributes to be predicated to God. By negating elements or negative attributes from God, one will attain a closer understanding of God.

As Maimonides highlighted that the ascription of corporeality to God is worse than idolatry. ${ }^{59}$ When one

\footnotetext{
${ }^{56}$ Maimonides, The Guide of the Perplexed, 72.

${ }^{57}$ Ibid., 76.

${ }^{58}$ Ibid.

59 Daniel Rynhold, An Introduction to Medieval Jewish Philosophy (London \& New York: I.B. Tauris, 2009), 80. See also Maimonides'
} 
ascribes attributes to God, it will lead to corporeal understanding of Him. Thus, logical argument such as the theory of negative attribution was observed by Maimonides as a strong tool in arguing against the physical description. ${ }^{60}$

Tracing the emergence of negative theology, Philo (20BC-50CE) was found to be among the earliest philosopher who rejects real attributes which was deduced from the scriptural reasoning of the unlikeness of God. It was later adopted by the Greek philosophers, Christian philosophers and followed by some of Muslim theologians, the Mu'tazilite. ${ }^{61}$ In the case of Maimonides, it seems probable that it was Ibn Sina who confers upon negative theology thus may have also utilized NeoPlatonic writings. ${ }^{6}$

Negative attributes repudiates any plurality and conveys the highest possibility of God. It is to achieve the knowledge of a God that is free from any human perception. The examples given by Maimonides are such as incorporeal, first, power, wisdom and will. Incorporeal needs to be negated for instance by saying that it is unlike the heavens which are material living. Next, first should

Responsa, trans. Joshua Blau, vol. 1 (Jerusalem: Meqitsei Nirdamim, 1989), 200.

60 This is especially needed during his time where Rabbinic anthropomorphism was ridiculed by the so called 'rationalist' scholars such as the Karaites and Muslim theologians.

61 Harry Austryn Wolfson, Repurcussion of the Kalam in Jewish Philosophy (US: Harvard University Press, 1979), 3-4. The negative theology can be traced to Plotinus that appears in Jewish Neoplatonic scholars such as Solomon Ibn Gabirol based on the notion of God's infinity. Elliot R. Wolfson, "Via Negativa in Maimonides and its Impact on Thirteenth-Century Kabbalah," in Maimonidean Studies Vol 5, eds. Arthur Hyman \& Alfred L. Ivry (New Jersey: Yeshiva University), 399.

62 Shlomo Pines, "The Philosophic Sources of The Guide of the Perplexed," in The Guide of the Perplexed: Moses Maimonides, 1963, xcv-xcvi. 
negate its existence due to any cause. As for power, wisdom and will it is neither weak nor ignorant and manage its production in an orderly manner without abandoning them. Maimonides observes that human's knowledge is insufficient to achieve the true comprehension of God. Thus, it is only through His actions or negative attribute human can apprehend His predicated attributes. ${ }^{63}$

Maimonides' negative theology was a strategy for preserving the utter and complete uniqueness of God while also not being rendered utterly silent and inarticulate in regard to God and divine attributes. Through the created order we understand that God is wise, benevolent, allpowerful, eternal, one, and unchanging. However, one must be careful in how one uses language about God because the unity of God's nature implies that predicating multiple attributes of God is already an error unless it is understood through negative theology.

To Maimonides, the more attributes one predicated to God, the further one will get from knowing the real Him. Maimonides mentions two consequences of affirming attributes to God. First, those attributes that one asserts are within their bound of intellect and is flawless according to their limited thinking. Second, by affirming attributes it leads to adding element to God's essence.

Therefore in predicating attributes to God, it will not lead to the absolute perfection of apprehending God as Maimonides noted, "God should not be the object of human comprehension, that none but only Himself comprehends what $\mathrm{He}$ is and that our knowledge consists in knowing that we are truly unable to comprehend Him". ${ }^{64}$

\footnotetext{
${ }^{63}$ Maimonides, The Guide of the Perplexed, 83.

${ }^{64}$ Ibid.
} 


\section{Incorporeality of God}

Anthropomorphism is a usual phenomenon in all primitive and ancient polytheistic religions. It is apparent in majority of Jewish literary sources mainly in the Bible, Aggadah and Midrashim. Yet, no material representation of deity should be accepted as a major axiom of Judaism. With regard to this issue, Maimonides strictly denied any form of corporeality to be subjected to God which includes apprehending God through anthropomorphic demonstration.

Maimonides defined univocal as something which constitutes the similar essential properties such as heat is the essential properties of fire and sun of fire and sun. Secondly, amphibolous which a term applied to two things because of the accidents that they have in common. For instance whiteness to a dog and cat is considered as an accident. Lastly equivocation which refers to a term that has no likeness at all between both unless for the similar word shared. Thus, anthropomorphic verses should be translated in an equivocal demonstration per se.

Maimonides' approach was evidently parallel with the Scripture's extensive use of descriptive terms in speaking of God. In the Hebrew Bible, God describes Himself as forgiving and merciful, long-suffering and patient, that God is generous and loving, that God becomes angry, and that God is jealous and insists on being the unique object of worship. For a great many people, the understanding of God, the commandments, and man's relationship with God depends heavily on the use of descriptively rich language.

Like some other medieval philosophers, Maimonides held that the same truth could be represented and conveyed by different means, in accordance to different levels of sophistication of understanding. For certain level of minds that are not capable to understand metaphysical principles and demonstrative proofs, they need to hear 
truth about God in idioms which are easily comprehensible. Alternatively, this could as well be articulated in terms of philosophical understanding.

It is apparent that Maimonides demonstrated his argument with the mind of Aristotle. ${ }^{65}$ His incorporeality is demonstrated through the threefold argument of His existence, unity and incorporeality. He argued the existence of God in conjunction with the agent who sets the sphere in motion through outlining four possibilities to the Agent; either corporeality or incorporeality or a force distributed throughout the whole sphere or indivisible force from the sphere.

The first case of corporeality is inadmissible. If the moving agent of the sphere is a corporeal being; it would therefore causes motion to itself in moving the sphere. Hence, it will require an infinite number of agents before the sphere is set for motion. The third argument proposes the force that is disseminated throughout the whole sphere as impossible. If the sphere is corporeal, therefore it succumbs to finite and motion is thus finite which is against the proposition of Aristotle that affirms the eternality of motion. Fourth argument resides on the indivisibility of force which causes the motion to be accidental. As accidental motion will cause motion to the agent one it is moved therefore accidental motion is finite and thus is not admissible to the agent. ${ }^{66}$

Hence, Maimonides affirmed that the second argument is construed to be the condition of the Prime

65 As quoted by Harry Wolfson on Aristotle's argument in his Metaphysic XII, 8, 1074a, 33-34 "If the Creator were a body...His power would be finite...but...the power of God is infinite and incessant, seeing that the celestial sphere is continuous in its motion, and so since God is not a body, there cannot accrue to Him any of the accidents of bodies.." Harry Wolfson, Maimonides on the Unity and Incorporeality of God, The Jewish Quaterly Review 56 (2) 1965, 115.

${ }^{66}$ Maimonides, Guide of the Perplexed, 150. 
Motor of the sphere, God. The cause of the sphere must be incorporeal in order to be eternal and infinite. It must also be neither divisible nor changeable and must not experience accidental moves.

\section{Conclusion}

It is well noted that the Jewish monotheistic concept of God was clearly elaborated by Maimonides during the middle age. The Islamic milieu of Almohad and the Andalusian scholarship certainly influenced Maimonides in several instances of his arguments. Maimonides' metaphor of philosophy which he phrased as 'apples of gold in settings of silver' truly demonstrates his attempt in harmonizing between religion and philosophy.

This can be observed when Maimonides understood the esoteric understanding of the verses as well as God is the Cause apart from being the Agent as described in the Law. The underlying meaning in understanding the text obviously signifies Maimonides belief that philosophy has been readily imbued within the law which Maimonides himself admitted that philosophy is "one of the foundations of our Law". Thus the synthesis between rabbinic tradition and philosophical proofs was apparent in Maimonides methods of demonstrating God's existence, unity and incorporeality.

It can be observed in God's existence, Maimonides affirmed that God is the Necessary Existent that cause other existences. His Essence is simple and does not consist of any added elements such as attributes. Thus God is the Intellect, the Agent of Intellect and the Object of Intelligible. This clearly explains Maimonides' emanative God which was advocated by Aristotle. This also illuminates the relation between God and man through the causal relation.

Apart from the causal relation, Maimonides affirmed God's role as an Agent as well which is manifested through His actions. Maimonides negated God's attributes 
and accepted actions to reflect God's relation with human because action does not reflect God's essence directly. Meanwhile attributes will cause multiplicity to God. In addition to his argument of unity, Maimonides totally negated attributes to God for the lesser description one puts on God, the more one will reach the knowledge of God. Maimonides' anticipation towards the negative theology clearly signifies his affiliation with the neoPlatonic theory. Similarly in affirming the incorporeality, Maimonides emphasized the allegorical interpretation in understanding the anthropomorphic verses.

Hence, it can be concluded that his philosophical anticipation was apparent in threefold; a) Maimonides' affirmation that philosophy is part of the revealed Law, b) Maimonides' argument on God as the Intellect, Intelligen and Intelligible, c) Maimonides' anticipation towards the theory of causation.

In sum, it can be observed that Maimonides' God is the philosophical God who emanates and cannot be known or described for certain within human's intellect. One can only perceive the knowledge of God through the perfection of intellectual quest. Meanwhile, according to Maimonides, it is ample for the laymen to understand the concept of equivocation in perceiving God.

\section{References}

Al-Faruqi, Ismail Raji. Islam dan Kepercayaan Lain (Islam and Other Faith). Kuala Lumpur: Institut Terjemahan Negara Malaysia Bhd, 2008.

Cook, Michael, "The Origins of Kalam," Bulletin of the School of Oriental and African Studies 43, 1980: 32-43.

Diesendruck, Z. "Maimonides' Theory of the Negation of Privation." Proceedings of the American Academy for Jewish Research, Vol. 6 (1934 - 1935): 139-151.

Flethcer, Madelaine. "Ibn Tumart's Teachers: The Relationship With al-Ghazālī”, Al-Qantara 18, 1997 : 305-330. 
Hartman, David \& Yagod, Elliott. "God, Philosophy and Halakhah in Maimonides' approach to Judaism." In Multiple Paths to God: Nostre Aetate, 40 Years, eds. John P. Hogan \& George F. McLean. Washington: The Council for Research in Values and Philosophy, 2005.

Ivry, Alfred. "Maimonides, The Guide of the Perplexed."

In The Classics of Western Philosophy: A Reader's Guide, eds. Jorge Garcia et al. Oxford: Blackwell Publishing Ltd., 2003.

Ivry, Alfred. The Cambridge Companion to Maimonides, ed. Kenneth Seeskin. Cambridge: Cambridge University Press, 2015.

Kreamer, Joel. "Moses Maimonides: An Intellectual Portrait." In The Cambridge Companion to Maimonides, ed. Kenneth Seeskin. Cambridge: Cambridge University Press, 2015.

Maimonides, Moses. The Guide of the Perplexed, tras. S. Pines. Chicago: University of Chicago, 1963.

Marx, Alexander, "Text by and About Maimonides", Jewish Quarterly Review: 374-381.

Pines, Sholomo. "Shi'ite Terms and Conceptions in the Kuzari," Jerusalem Studies in Arabic and Islam 2: 165251.

Reese, William. Dictionary of Philosophy and Religion. New Jersey: Humanities Press, 1980.

Rosner, Fred. "The Life of Moses Maimonides, a Prominent Medieval Physician," Einstein Quarterly, 19. 2002: 125-128.

Rudavsky, Tamar. Maimonides. Oxford: Wiley Blackwell, 2010.

Rynhold, Daniel. An Introduction to Medieval Jewish Philosophy. London \& New York: I.B. Tauris, 2009.

Segal, Eliezer. Introducing Judaism. New York: Taylor and Francis Group, 2009. 
Nurhanisah, Wan Adli \& Khadijah, "Concept of God according to Moses Ben Maimon,” Afkār Vol. 18 Special Issue (2016): 165-198

Stroumsa, Sarah. Maimonides in His World: Portrait of a Mediterranean Thinker. Oxforshire: Princeton University Press, 2009.

Wolfson, Elliot R. "Via Negativa in Maimonides and its Impact on Thirteenth-Century Kabbalah." In Maimonidean Studies Vol 5, eds. Arthur Hyman \& Alfred L. Ivry. New Jersey: Yeshiva University.

Wolfson, Harry Austryn. "Maimonides in the Unity and Incorporeality of God," The Jewish Quaterly Review 56 (2) 1965: 112-136.

Wolfson, Harry Austryn. Repurcussion of the Kalam in Jewish Philosophy. US: Harvard University Press, 1979.

Wolfson, Harry Austryn. The Philosophy of the Kalam. Cambridge: Harvard University, 1976. 
Nurhanisah, Wan Adli \& Khadijah, "Concept of God according to Moses Ben Maimon," Afkār Vol. 18 Special Issue (2016): 165-198 